\title{
FEDERAL PREEMPTION UNDER THE RAILWAY LABOR ACT: TRADITIONAL VS. ESSENTIAL STATE FUNCTIONS IN THE CONTEXT OF COMMUTER TRANSIT SYSTEMS
}

In recent years many state and local governments have purchased transit companies to provide urban commuter services to residents. ${ }^{1}$ If such a governmentally owned commuter-rail system provides no freight services, the system is exempt from the coverage of the Railway Labor Act (RLA)2 under the exemption for "street, interurban, or suburban electric railway[s]." 3 In some instances, however, the state or local government continues to provide both the commuter and the freight services of the newly acquired company. In formulating their labor policies, these governments inust determine whether their status as employers is governed by the RLA, which covers all interstate carriers, ${ }^{4}$ or by the National Labor Relations Act, ${ }^{5}$ which specifically exempts "any State or pohtical subdivision thereof" from coverage. ${ }^{6}$

Despite Congress's concern with preserving einployee rights under preexistimg contracts, ${ }^{7}$ state governments operating newly acquired systems liave often asserted that their governmental status entitles them to subordinate employee rights to state or local policy. ${ }^{8}$ Relying on the

1. See generally K. Jennings, JR., J. SMtth, JR. \& E. Trayham, JR., LAboR Relations IN a Public Service Industry: Unions, Management and the Public Interest in Mass Transit (1978); Barnum, From Private to Public: Labor Relations in Urban Transit, 25 Indus. \& LAB. ReL. Rev. 95 (1971); Hall, Hert, Sickles \& Walsh, Collective Bargaining Considerations at the Time of Public Acquisition of a Private Transit Company, 2 Transit L. Rev. 5 (1981). Professor Barnum postulates that the deteriorating position of private transit companies, declining patronage, and increasing expenses have caused the shift from private to public ownership. Barnum, supra, at 99 .

2. 45 U.S.C. $\S \S 151-188$ (1976).

3. $I d . \S 151$.

4. Id.

5. 29 U.S.C. $\$ \S 151-169$ (1976).

6. Id. \& 152(2).

7. See H.R. ReP. No. 204, 88th Cong., 1st Sess. 15-16, 28-29, reprinted in [1964] U.S. CODE CONG. \& AD. NEws 2569, 2583-85, 2595-97.

8. See, e.g., Umited Transp. Umion v. Long Island R.R., 634 F.2d 19 (2d Cir. 1980), cert. granted, 101 S. Ct. 3107 (1981); Local Div. 519, Amalgamated Transit Union v. LaCrosse Mun. Transit Util., 585 F.2d 1340 (7th Cir. 1978); Division 1287, Amalgamated Transit Umion v. Kansas City Area Transp. Auth., 582 F.2d 444 (8th Cir. 1978), cert. denied, 439 U.S. 1090 (1979); Brotherlrood of Locomotive Eng'rs v. Staten Island Rapid Transit Operating Auth., 100 L.R.R.M. 3154 (E.D.N.Y. Feb. 9, 1979); City of Macon v. Marshall, 439 F. Supp. 1209 (M.D. Ga. 1977); Staten 
Supreme Court's decision in National League of Cities v. Usery, ${ }^{9}$ state and local governments often assert that their operation of a local commuter system is exempt from congressional legislation enacted pursuant to the commerce power. ${ }^{10}$

Judicial confusion exists over the limits of Usery. Two shortcoinmgs of Justice Rehnquist's opinion foster this confusion: his failure to define "integral governmental functions" 11 and his use of a number of

Island Rapid Transit Operating Auth. v. IBEW Local 922, 57 A.D.2d 614, 393 N.Y.S.2d 773, appeal denied, 42 N.Y.2d 804, 397 N.Y.S.2d 1028, cert. denied, 434 U.S. 934 (1977).

9. 426 U.S. 833 (1976).

10. See, e.g., United Transp. Union v. Long Island R.R., 634 F.2d 19 (2d Cir. 1980), cert. granted, 101 S. Ct. 3107 (1981); Brotherhood of Locomotive Eng'rs v. Staten Island Rapid Transit Operating Auth., 100 L.R.R.M. 3154 (E.D.N.Y. Feb. 9, 1979); Staten Island Rapid Transit Operating Auth. v. IBEW Local 922, 57 A.D.2d 614, 393 N.Y.S.2d 773, appeal denied, 42 N.Y.2d 804, 397 N.Y.S.2d 1028, cert. denied, 434 U.S. 934 (1977). See also City of Macon v. Marshall, 439 F. Supp. 1209 (M.D. Ga. 1977).

11. See National League of Cities v. Usery, 426 U.S. 833, 851 (1976). Rather than attempt to formulate a definition for an integral governmental function, Justice Rehnquist listed several state services that he deeined immune froin federal legislation under the conmerce clause: "such areas as fire prevention, police protection, sanitation, public health, and parks and recreation." Id. at 851. By overruting Maryland v. Wirtz, 392 U.S. 183 (1968), the Court inplied that hospitals, schools for the handicapped, elenientary and secondary schools, and institutions for higher education would also be protected. See Amersbach v. City of Cleveland, 598 F.2d 1033, 1036-37 (6th Cir. 1979). In Usery, the Court noted, however, that "It]lhese exaniples are obviously not an exhaustive catalogue of the numerous line and support activities which are well within the area of traditional operations of state and local governments." 426 U.S. at 851 n.16.

One commentator has argued that the hitany of terms used by Justice Rehnquist to describe those areas immune from congressional legislation compounds the confusion surrounding the definition of an "essential" (integral) state function. Note, National League of Cities Crashes on Takeoff: Balancing Under the Commerce Clause, 68 GEo. L.J. 827, 836 n.60 (1980). This litany includes " 'functions essential to separate and independent existence," " 426 U.S. at 845 (citation omitted); "those governmental services which their citizens require," id. at 847; "traditional ways in which the local governments have arranged their affairs," id. at 849; and "functions . . . which governments are created to provide, services . . . which the States have traditionally afforded their citizens." Id. at 851 .

In order to aid the interpretation of what constitutes an integral state function, the United States Department of Labor has listed eight functions of a state or political subdivision that the Department does not consider integral:

1. Alcoholic beverage stores,

2. Off-track betting corporations,

3. Local mass transit systems,

4. Generation and distribution of electric power,

5. Provision of residential and commercial teleplione and telegraphic communication,

6. Production and sale of organic fertilizer as a by-product of sewage processing,

7. Production, cultivation, growing or harvesting of agricultural commodities for sale to consumers, and

8. Repair and maintenance of boats and marme engines for the general public.

29 C.F.R. $\S 775.3$ (1981) (effective dates omitted) (emphasis added).

See also Fox, Federal Public Sector Labor Relations Legislation: The Aftermath of National League of Cities v. Usery, 26 U. KAN. L. REv. 105, 115-16 (1977) (by faiting to confront the notion of state sovereignty, the Court failed to undertake a fundaunental reexamination of the relationship between the national government, state governments, and the people); Matsumoto, National 
terms to describe these functions. In determining the nature of an integral state function, Justice Rehnquist cited to cases that distinguished between governmental and proprietary state functions and held that Congress could not exercise the commerce power "to directly displace the States' freedom to structure integral operations in areas of traditional governmental functions." 12

Judicial ${ }^{13}$ criticisms of the governmental-proprietary distinction and professional ${ }^{14}$ criticisms of Usery indicate that the Court's failure to define these functions precisely has led to uncertainty in applying the concepts underlying the Usery decision. The Court's failure stems from trying to accommodate two conflicting goals. First, the Court has used the distinction to try to preserve an active role for state and local governments in a federal system, ${ }^{15}$ thereby allowing these governments to provide the services that their citizens demand without unwarranted federal interference. ${ }^{16}$ Second, the Court has used the test to allow

League of Cities-From Footnote to Holding-State Immunity from Commerce Clause Regulation, 1977 ARIz. ST. L.J. 35, $72-76$ (meaning of "traditional" (integral) state function uncertain); Note, State Sovereignty and the Commerce Power-State Employees Exempt from Federal Minimum Wage Law: National League of Cities v. Usery, 9 CoNN. L. Rev. 691, 696-97 (1977) (Usery provides no meaningful guidelines to determine which state functions are imtegral); Note, The Essential Governmental Function After National League of Cities: Impact of an Essentiality Test on Commuter Rail Transportation, 9 FORDHAM URB. L.J. 149 (1980) (Court did not satisfactorily delineate essential (integral) state functions froin other governmental activities); Comment, Constitutional Law-Commerce Power Limited to Preserve States' Role in the Federal System, 30 RUTGERS L. Rev. 152, 168-69 (1976) (lack of clarity of Usery standard will hinder application); Note, National League of Cities v. Usery: A New Approach to State Sovereignty?, 48 U. CoLo. L. REv. 467, 476 (1977) (Usery provides no standard to resolve conflicts between state and national power); 25 EMORY L.J. 937, 954 (1976) (indefiniteness of standard may lead Court to apply law "capriciously").

12. 426 U.S. at 852 . Justice Relinquist contrasted traditional state functions with the proprietary operation of a railroad in United States v. California, 297 U.S. 175 (1936). Such an activity "was not in an area that the States have regarded as integral parts of their governmental activities. It was, on the contrary, the operation of a railroad engaged in 'common carriage by rail in imterstate commerce ...." 426 U.S. at 854 n.18.

13. See, e.g., Employees of the Dep't of Pub. Health \& Welfare v. Department of Pub. Health \& Welfare, 411 U.S. 279, 297 n.11 (1973) (Marshall, J., concurring); Indian Towing Co. v. United States, 350 U.S. 61, 65 (1955); New York v. United States, 326 U.S. 572, 580 (1946) (opinion of Frankfurter, J.); id. at 586 (Stone, C.J., concurring).

14. See, e.g., Bogen, Usery Limits on Natural Interest, 22 ARuz. L. Rev. 753 (1980); Michelinan, States' Rights and States' Roles: Permutations of 'Sovereignty" in National League of Cities v. Usery, 86 YALE L.J. 1165 (1977); Schwartz, National League of Cities v. Usery-The Commerce Power and State Sovereignty Redivivus, 46 FordHAM L. Rev. 1115 (1978); Tribe, Unraveling National League of Cities: The New Federalism and Affirmative Rights to Essential Government Services, 90 HARv. L. Rev. 1065 (1977). See generally Wells \& Hellerstein, The Governmental-Proprietary Distinction in Constitutional Law, 66 VA. L. REv. 1073 (1980).

15. See generally Wells \& Hellerstein, supra note 14, at 1075-78, 1080-85 (distinction aids accommodation of federal interests in taxation or regulation and states' interest in immunity).

16. See New York v. United States, 326 U.S. 572, 591 (1946) (Douglas, J., dissenting) ("[w]hat might have been viewed in an earlier day as an improvident or even dangerous extension 
Congress to legislate in areas that require comprehensive treatment without state and local interference. ${ }^{17}$

This comment first discusses the problem confronted in Usery: determining which state activities are immune froin federal regulation. Drawing support from cases involving intergovernmental immunity in the tax and antitrust fields, the comment proposes an analytical framework that explains $U$ sery. The framework first divides governmental functions into two classes: traditional functions, defined as those services provided by states in $1787,{ }^{18}$ the year the Constitution was drafted, and essential functions, defined as those services that state and local governments have undertaken since 1787 to meet their citizens' expectations. ${ }^{19}$ The analysis then requires a balancing of the asserted state and federal interests.20 Under this part of the framework the federal government inust overcoine a heavy burden before applying its legislation to traditional functions. If the service is essential, however, state governments inust show a demonstrably greater interest in providing the service without federal interference than the federal interest in regulating the service to prove undue federal interference with the activity. Finally, the comment argues that the federal interests in urban mass transit and im a comprehensive labor scheme do not unduly interfere with the essential state function of providing commuter and freight rail service and therefore that the RLA preempts the application of contrary state and local law.

\section{The Problem After National League of Cities V. Usery: Defining State Functions That Are Immune From FEDeral Regulation}

In National League of Cities $v$. Usery ${ }^{21}$ the Supreme Court de-

of state activities may today be deemed indispensible"); Amersbach v. City of Cleveland, 598 F.2d 1033, 1037 (6th Cir. 1979) ('the terms 'traditional' or 'integral' are to be given a meaning permitting expansion to ineet changing times"). See generally Michelman, supra note 14, at 1173-80.

17. See, e.g., California v. Taylor, 353 U.S. 553, 566-67 (1957); Indian Towing Co. v. United States, 350 U.S. 61, 64-65 (1955); United States v. California, 297 U.S. 175, 184-85 (1936). See also Mississippi v. Federal Energy Regulatory Comm'n, No. J79-0212(C) (S.D. Miss., Feb. 19, 1981), cert. granted, $101 \mathrm{~S}$. Ct. 3077 (1981). In this case the district court addressed the analogous issue of whether Congress may supplement and modify state regulation of intrastate public utilities. The question differs froun that discussed in this comment in that it focuses on the power of the federal government to regulate a private industry historically regulated by the state through state regulatory apparatus. This comment concerns the extent of the federal government's power to regulate the state as a provider of services.

18. See note 136 infra and accompanying text.

19. See note 138 infra and accompanying text.

20. See note 136-39 infra and acconpanying text.

21. 426 U.S. 833 (1976). 
clared the 1974 amendments to the Fair Labor Standards Act (FLSA) ${ }^{22}$ unconstitutional. These amendments had extended minimum wage and maximum hour provisions to employees of state and local governments. ${ }^{23}$ The cities and states successfully argued that this legislation violated "an affirmative limitation on the exercise of [congressional] power akin to other commerce power affirmative limitations contained in the Constitution." 24 Writing for the plurality, ${ }^{25}$ Justice Rehnquist analogized to cases imvolving state immunity from the federal tax power and held that certain state functions lay beyond the scope of the commerce power. ${ }^{26}$ Although employment conditions of state and local government employees affect interstate commerce, ${ }^{27}$ the Court held that Congress inay not act to "directly displace the States' freedom to strueture integral operations in areas of traditional governmental functions."'28 This limitation derives from the tenth amendment and the nature of a federal system. ${ }^{29}$

Justice Rehnquist's plurality opinion indicates that a judicial determination of whether a congressional statute interferes with a "traditional governmental function" is the most important step in the inquiry. To Justice Rehnquist the only issue was whether Congress, in enacting the FLSA amendments, had breached the affirmative doctrine of inter-governmental immunity. ${ }^{30}$ Finding such a breach, Justice Rehnquist held the amendments unconstitutional. ${ }^{31}$ Concurring in the

22. 29 U.S.C. $\& 203(d)$ (1974 Supp. IV).

23. Id; 426 U.S. at 836.

24. 426 U.S. at 841 . Justice Rehnquist also stated that the Court's previous decisions recognized "that there are attributes of sovereignty attaching to every state government which may not be impaired by Congress, not because Congress may lack an affirmative grant of legislative authority to reach the matter, but because the Constitution prohibits it from exercising the authority in that manner." Id. at 845 .

25. Justices Stewart and Powell and Chief Justice Burger joined Justice Rehnquist's opinion. Justice Blackmun concurred separately. Id. at 856 . Justice Brelman dissented, jomed by Justices White and Marshall. Id. Justice Stevens dissented separately. Id. at 880.

26. Id. at 843 (citing New York v. Umited States, 326 U.S. 572 (1946)); 426 U.S. at 844 (citing Metcalf \& Eddy v. Mitchell, 269 U.S. 514 (1926)). See notes 110-35 infra and accompanying text.

27. 426 U.S. at $848-49$.

28. Id. at 852 .

29. Id. at 842-44. U.S. ConsT. amend. $\mathrm{X}$ provides that: "The powers not delegated to the United States by the Constitution, nor prohibited by it to the States, are reserved to the States respectively, or to the people." In Fry v. United States, 421 U.S. 542, 547 n.7 (1975) the Court stated: "The [Tenth] Amendment expressly declares the constitutional policy that Congress may not exercise power in a fashion that impairs the States' integrity or their ability to function effectively in a federal system."

30. 426 U.S. at 841 .

31. "Congress has attempted to exercise its commerce clause authority to prescribe minimum wages and maximum hours to be paid by states in their capacities as sovereign governments. In so doing, Congress has sought to wield its power in a fashion that would impair the States' 'ability to function effectively in a federal system." " $I d$. at 852. 
result, Justice Blackmun specifically adopted a balancing approach that permits federal regulation of traditional state functions "where the federal interest is demonstrably greater and where state . . . compliance . . . would be essential." 32 He concurred with the plurality because he believed that they implicitly adopted a balancing approach. ${ }^{33}$

Justice Rehnquist's analysis in Usery of two previous commerce power cases suggests that the plurality did implicitly adopt a balancing approach. In Fry v. United States ${ }^{34}$ the Court had upheld the constitutionality of the Economic Stabilization Act of 1970 (ESA), ${ }^{35}$ which limited wage increases granted to state and local government employces. Writing for the Fry majority, Justice Marshall had stated that the Act's language and legislative history implied that Congress intended the Act to apply to all employees. ${ }^{36}$ In reaffirming Fry in the Usery opinion, Justice Rehnquist distinguished the ESA from the 1974 FLSA amendments by noting that the ESA was an einergency measure intended to solve a national problem. ${ }^{37}$ Significantly, Justice Rehnquist had dissented in Fry, reasoning that the ESA affected the states' constitutional right "inherent in [their] capacity as State[s], to be free from such congressionally asserted authority." 38

A balancing approach also explains the Usery Court's overruling of Maryland $v$. Wirtz ${ }^{39}$ In Wirtz the Court had upheld the constitutionality of the 1966 FLSA amendments, which liad extended the Act's coverage to state-operated hospitals, elementary and secondary schools, and institutions of higher learning. ${ }^{40}$ The Usery plurality recognized a

32. Id. at 856 .

33. $I d$.

34. 421 U.S. 542 (1975).

35. Act of Aug. 15, 1970, Pub. L. No. 91-379, $\S \S 201-06,84$ Stat. 799.

36. 421 U.S. at 545-48. The Act made no exceptions for any federal or state governmental employees. Id. at 546. Justice Marshall noted: "II]n framing the Act, Congress specifically rejected an amendment that would have exempted employces of state and local governments. 117 Cong. Rec. 43,673-77 (1971). And the Senate Committee Report makes it plain that the Committee considered and rejected a proposed exemption for the same group. S. REP. No. 92-507, p. 4 (1971)." 421 U.S. at 546. He also noted that state employees constituted fourteen percent of the nation's work force. If the Court had exempted state employees from coverage, "the effectiveness of federal action would have been drastically impaired." Id. at 548.

37. Natioual League of Cities v. Usery, 426 U.S. 833, 853 (1976). Justice Rehnquist emphasized that "[t]he means selected [in the Economic Stabilization Act] were carefully drafted so as not to interfere with the States' freedom beyond a very limited, specific period of time." Id. Justice Rehnquist then argued that the across-the-board freeze authorized by the Act did not displace state policy choices in the saine way that the 1974 FLSA amendments did. Id.

38. 421 U.S. at 553.

39. 392 U.S. 183 (1968).

40. 29 U.S.C. $\S 203 d$ (1976). In Wirtz the Court stated that "the Federal Government, when acting within a delegated power, may override state interests whether these be described as 'govermmental' or 'proprietary' in character." Maryland v. Wirtz, 392 U.S. 183, 195 (1968). The Court 
distinction between hospital or school employees and other governinental personnel, ${ }^{41}$ but implicitly found that no overriding federal concern warranted blanket coverage of these state functions..$^{42}$

Two probleins have confronted courts ${ }^{43}$ and commentators ${ }^{44}$ attempting to analyze Usery: Justice Rehnquist's failure to provide a clear definition of an imtegral state function, and his refusal to recognize explicitly the role that the asserted federal interest plays in the analysis. These shortcomings have led to particularly divergent analyses when courts have attempted to determine whether the RLA preeinpts state labor legislation where a state or local government provides both freight and commuter-rail services to its citizens.

\section{Judicial ANalysis of the Applicability of Federal RaIlroad STATUTES to State-Operated COMMUTER LINES}

Generally, courts faced with a conflict between the RLA and state statutes have disagreed im the first instance whether a balancing test is appropriate in deciding which statute to apply. Even those courts that agree that a balancing test is appropriate have differed on the consideration to be accorded the impact of the commuter-freight systein on interstate commerce. ${ }^{45}$

refused to "carve up the commerce power to protect enterprises indistinguishable in their effect on cominerce from private businesses, simply because those enterprises happen to be run by the States for the benefit of their citizens." Id. at 198-99. Justices Douglas and Stewart dissented on the grounds that the FLSA amendments were "pervasive, striking at all levels of state governinent," disrupted state fiscal policy, and threatened their autonomy in the regulation of health and education. Id. at 202-03.

41. National League of Cities v. Usery, 426 U.S. 833, 855 (1976).

42. Id. at 853-54.

43. See, e.g., United Transp. Union v. Long Island R.R., 634 F.2d 19 (2d Cir. 1980), cert. granted, 101 S. Ct. 3107 (1981); Peel v. Florida Dep't of Transp., 600 F.2d 1070 (5th Cir. 1979); Amersbach v. City of Cleveland, 598 F.2d 1033 (6th Cir. 1979); Friends of the Earth v. Carey, 552 F.2d 25 (2d Cir.), cert. denied, 434 U.S. 902 (1977); Alewine v. City Council, 505 F. Supp. 880 (S.D. Ga. 1981).

44. See, e.g., Bogen, supra note 14, at 763-71; Matsumoto, supra note 11, at 71 n.193 (plurality opmion rejects balancing approach); Michelman, supra note 14, at 1173-81 ("essential" status conferred by the acts of the electorate); Tribe, supra note 14, at 1072-80; Tushnet, Constitutional and Statutory Analyses in the Law of Federal Jurisdiction, 25 U.C.L.A. L. REv. 1301, 1338, 1340 (1978).

45. Compare United Transp. Union v. Long Island R.R., 634 F.2d 19 (2d Cir. 1980), cert. granted, 101 S. Ct. 3107 (1981) and Staten Island Rapid Transit Operating Auth. v. IBEW Local 922, 57 A.D.2d 614, 393 N.Y.S.2d 773, appeal denied, 42 N.Y.2d 804, 397 N.Y.S.2d 1028, cert. denied, 434 U.S. 934 (1977) with United Transp. Union v. Long Island R.R., 509 F. Supp. 1300 (E.D.N.Y.), rev'd 634 F.2d 19 (2d Cir. 1980), cert. granted 101 S. Ct. 3107 (1981) and Brotherhood of Locomotive Eng'rs v. Staten Island Rapid Transit Operating Auth., 100 L.R.R.M. 3154 (E.D.N.Y. Feb. 9, 1979). 
In Staten Island Rapid Transit Operating Authority (SIRTOA) $v$. $I B E W$, Local $922,{ }^{46}$ SIRTOA operated a single-line commuter railway and a limited freight service. ${ }^{47}$ The employees of SIRTOA argued that the RLA preempted New York's Taylor Law, which prohibits strikes by public einployees, ${ }^{48}$ and that the state court therefore could not apply that law to enjoin a strike. ${ }^{49}$ In rejecting the employees' contention, the court held that the operation of a railroad in interstate commerce is not a state function protected from congressional regulation by principles of state sovereignty. ${ }^{50}$ The court determined, however, that SIRTOA was "essentially an imtrastate passenger or commuter operation" and was not operating a railroad as a common carrier. ${ }^{51}$ Ignoring the federal interests in commuter transportation ${ }^{52}$ and comprehensive labor legislation, ${ }^{53}$ the court concluded that the state's interest in preventing strikes by public employees and in providing rail service to commuters was greater than any federal interest arising from SIRTOA's "minimal and tenuous connection to interstate commerce." 54

Another court, however, has applied the RLA despite the limited

46. 57 A.D.2d 614, 393 N.Y.S.2d 773, appeal denied, 42 N.Y.2d 804, 397 N.Y.S.2d 1028, cert. denied, 434 U.S. 934 (1977).

47. At one time ... the Staten Island railway line was truly a part of an interstate system. At the time of the city's acquisition, the connection between the railway and interstate commerce had dwindled to the operation of one freight train per day over this trackage. Continuation of this service was a condition of the city's takeover.

57 A.D.2d at 614, 393 N.Y.S.2d at 774.

48. N.Y. Crv. SERv. LAW $\$ 210$ (McKinney 1973). See generally Douglas, The Labor Injunction: Enjoining Public Sector Strikes in New York, 31 LAB. L.J. 340 (1980) (summarizing the provisions and the effects of the Taylor Law).

49. 57 A.D.2d at $614-15,393$ N.Y.S.2d at 774-75.

50. Id. at 615,393 N.Y.S.2d at 775 (citing National League of Cities v. Usery, 426 U.S. 833, 854 n.18 (1976)).

51. Citing California v. Taylor, 353 U.S. 553 (1957) (discussed at notes $93-96$ infra and accompanymg text), the court noted that "[t]here is no doubt that when a state or one of its political subdivisions owns and operates a railroad which is directly engaged in interstate commerce, it thereby subjects itself to the commerce power and that Congress can regulate its employment relationships." 57 A.D.2d at 615,393 N.Y.S.2d at 775. "SIRTOA's operation is in no way comparable to the State-owned switching or terminal railroads lield subject to Federal jurisdiction . . ." Id. at 615-16, 393 N.Y.S.2d at 775. The court also enphasized that the Interstate Commerce Commission liad recognized the tenuous connection between SIRTOA and imterstate commerce by exempting SIRTOA from various provisions of the Interstate Commerce Act. Id. at 616, 393 N.Y.S.2d at 775.

52. Sce notes 191-94 infra and accompanying text.

53. See notes 195-210 infra and accompanying text. The court noted that SIRTOA's employees came within the literal coverage of the RLA. Nevertheless, the court concluded that SIRTOA's labor dispute did not present problems of national or regional magnitude. 57 A.D.2d at 616,393 N.Y.S.2d at 775.

54. Id. at 616,393 N.Y.S.2d at 776. 
nature of SIRTOA's one-train freight operation. ${ }^{55}$ In Brotherhood of Locomotive Engineers v. Staten Island Rapid Transit Operating Authority ${ }^{56}$ a federal district court held that the RLA preempts contrary state provisions under the supremacy clause of the federal Constitution ${ }^{57}$ and that therefore SIRTOA could not invoke the Taylor Law. ${ }^{58}$ The court did not discuss the state's alleged significant interest in curtailing public employee strikes or the tenuous connection between SIRTOA and interstate commerce. ${ }^{59}$ In refusing to grant SIRTOA the injunction, the court emphasized that the RLA was a comprehensive effort to stabilize employment relationships in an important national industry. ${ }^{60}$ In United Transportation Union (UTU) v. Long Island Railroad $(L I R R)^{61}$ a panel of the Court of Appeals for the Second Circuit enjomed employees of New York's Metropolitan Transportation Authority (MTA) from engaging in self-help under the RLA. Like SIRTOA, the MTA had acquired its rail line from a private company. ${ }^{62}$ The MTA operated the line both as a commuter system and as an interstate carrier, handling from 800 to 1000 freiglit cars per week. ${ }^{63}$ The MTA assumed that the RLA covered its operations and took specific action to curtail employee rights: faced with the possibility of a strike, the MTA converted the LIRR from a private stock corporation to a public benefit corporation in order to enjoin the strike under the Taylor
55. See note 47 supra and accompanying text.
56. 100 L.R.R.M. 3154 (E.D.N.Y. Feb. 9, 1979).
57. U.S. Const. art. VI, cl. 2:

This Constitution, and the Laws of the Umited States which shall be made in Pursuance thereof; and all Treaties made, or which shall be inade, under the Authority of the United States, shall be the supreme Law of the Land; and the Judges in every State shall be bound thereby, any Thing in the Constitution or Laws of any State to the Contrary notwithstanding.

58. But see Staten Island Rapid Transit Operating Auth. v. IBEW Local 922, 57 A.D.2d 614, 616, 393 N.Y.S.2d 773, 775 appeal denied, 42 N.Y.2d 804, 397 N.Y.S.2d 1028, cert. denied, 434 U.S. 934 (1977).

59. 100 L.R.R.M. at 3160-61. "Not a single authority has been cited to this court which even suggests that we should engage in a quantitative analysis, debilitating the Act in some proportionate ineasure as the connection with interstate commerce decreases." Id.

60. Id. at 3158-60. "While we recognize the strong local interest in maintaining the operation of a railway system such as SIRTOA, we reject the assertion that such interest validates an unquestionable abridgement of federally guaranteed rights." $I d$ at 3159 . The court also noted that "none of the [labor] preenption cases . . . stand for the proposition that conduct . . . at the core of . . federal [labor] legislation inust give way to contrary local regulation." Id. at 3160 n.8 (citations omitted). See notes 195-210 infra and accompanying text.

61. 634 F.2d 19 (2d Cir. 1980), cert. granted, 101 S. Ct. 3107 (1981).

62. 634 F.2d at 20.

63. Id. at 20. The court emphasized, however, that the revenue froin freight operations, $\$ 12.1$ million in 1979, constituted only a sinall portion of the estimated $\$ 300$ million income. Id. at 2021. The panel concluded that the LIRR was essentially a local commuter transit system exeinpt froin the RLA. Id. at 20. 
Law. ${ }^{64}$ In reversing the district court, ${ }^{65}$ the panel held that the RLA impaired "the State's ability to structure einployer-employee relationships in its role as sole provider of an essential public service."66

Applying a balancing test, ${ }^{67}$ the panel conceded that the LIRR was facially subject to the RLA. ${ }^{68}$ The panel, however, focused on the purpose of the Taylor Law ${ }^{69}$ and emphasized the state's interest im providing commuter rail service. ${ }^{70}$ Relying on Justice Blackınun's concurrence in Usery, ${ }^{71}$ the panel concluded that the union had failed to present a "demonstrably greater" federal interest and that the state was entitled to an mjunction under the Taylor Law. ${ }^{72}$

The courts' divergent analyses make generalizations difficult. Given the Supreme Court's historically broad view of interstate com-

64. Id. at 21 .

65. Id at 20. The district court attached importance to the MTA's conversion of the LIRR into a "pubhic benefit subsidiary corporation" specifically in order to subject the employees to the Taylor Law. United Transp. Union v. Long Island R.R., 509 F. Supp. 1300 (E.D.N.Y.), rev'd 634 F.2d 19 (2d Cir. 1980), cert. granted 101 S. Ct. 3107 (1981). Noting that the LIRR was the only common carrier serving numerous industries and the traveling public in Nassau and Suffolk counties, id. at 1304, Judge Mishler held that a balancing test was not appropriate:

'Whether the source of this right be found in a particular provision of the Railway Labor

Act or in the scheme as a whole, it is integral to the Act. State courts may not enjoin a

peaceful strike by covered railway einployees, no inatter how economically harmful the

consequences inay be.'

Id. at 1305 (quoting Brotherhood of R.R. Trainmen v. Jacksonville Terminal Co., 394 U.S. 369, 384-85 (1969)).

66. 634 F.2d at 20 .

67. Id at 23-24, 29-30. The court failed to note, however, the comprehensiveness of the federal labor scheme in general and of the RLA in particular.

68. Id at 22-23. The court also noted that the LIRR's freight service provides a crucial physical link with other interstate rail carriers. Historically, the LIRR had always considered itself a carrier within the neaning of the RLA and lad consistently filed reports required by the Interstate Commerce Act. Moreover, the einployees receive benefits under the Railroad Rctirement Act, the Railroad Unemployinent Insurance Act, and the Federal Einployees Liability Act. Id. at 23.

69. Id at 25. "In enacting the Taylor Law, New York State made a determination that in order to protect the public it inust assure the orderly and uninterrupted operations and functions of government by prohibiting strikes by public employees."

70. Id. at 26-27. The court used two grounds to distinguish a passenger rail service from a common freight carrier. First, the court classified the LIRR as a service that state and local governments are particularly suited to provide because of community-wide need: "it is a service they have come to provide by a process of economic elimination of private suppliers." Id. at 27 . Second, the court conpared the importance of the LIRR's passenger service to a state operated freight line. Id. See also Amersbach v. City of Cleveland, 598 F.2d 1033, 1037-38 (6th Cir. 1979) (municipal airport is an integral function of city government); New York City Transit Auth. v. Loos, 2 Misc. 2d 733, 736, 154 N.Y.S.2d 209, 212-13 (Sup. Ct. I956), affd 3 A.D.2d 740, 161 N.Y.S.2d 564 (1957).

71. National League of Cities v. Usery, 426 U.S. 833, 856 (1976) (Blackmun, J., coucurring) (federal regnlation will be upheld if federal interest is "demonstrably greater" than the state's interest). See text acconupanying notes 32-33 supra.

72. 634 F.2d at 24 . 
merce, ${ }^{73}$ any analysis that focuses exclusively on the existence of an impact on interstate commerce appears unjustified. The proper focus should be on whether the commuter-freight system has sufficient dealings involving interstate commerce to warrant classification as a cominon carrier under the RLA.

The Supreme Court has never directly addressed whether staterun commuter lines are immune from federal labor regulation. In two pre-Usery decisions related to this issue, the Court refused either to enjoin a strike by employees of a private company or to permit the States to operate a private utility when a labor strike threatened the utility's continued operation.

In Amalgamated Association of Street Employees, Division $988 v$. Wisconsin Employment Relations Board ${ }^{74}$ the union challenged the constitutionality of the Wisconsin Public Utility Anti-Strike Law. ${ }^{75}$ That statute prohibited employees of private transit companies fron engaging in strikes that would interrupt an "essential pubhc utility service." 76 The Court held that the statute conflicted with the National Labor Relations Act (NLRA) and was therefore invalid under the supreinacy clause. ${ }^{77}$ The Court rejected the Board's arguinent that a state statute that affected a private company operating in interstate commerce and that also conflicted with federal labor legislation could be saved merely by designating it as " "emergency' legislation."78

In Division 1287 of the Amalgamated Association of Street Employees v. Missouri ${ }^{79}$ the Supreme Court refused to allow the governor of

73. See Katzenbach v. McClung, 379 U.S. 294 (1964); Wickard v. Filburn, 317 U.S. 111 (1942); NLRB v. Jones \& Laughlin Steel Corp., 301 U.S. 1 (1937).

74. 340 U.S. 383 (1951).

75. WIS. STAT. § 111.62 (1949).

76. Id. The statute provided: "It shall be unlawful for any group of employes [sic] of a public utility employer acting in concert to call a strike or to go out on strike, or to cause any work stoppage or slowdown which wonld cause an interruption of an essential service . . ."

77. 340 U.S. at 399. Section 7 of the National Labor Relations Act provides: "Employees shall liave tlie right to self-organization, to form, join, or assist labor organizations, to bargain collectively through representatives of their own choosing, and to engage in other concerted activities for the purpose of collective bargaining or other mutual aid or protection . . . " 29 U.S.C. $\S 157$ (1976).

78. 340 U.S. at 393-96. Chief Justice Vinson, speakmg for the Court, commented that the Wisconsin act was not emergency legislation but a comprehensive code for the settlement of labor disputes between pubhic-utility einployers and employees. The act sought to deny a federally guaranteed right and therefore could not withstand constitutional scrutiny. Id.

It is important to note that the NLRA "cannot be imported wholesale into the railway labor arena." Brotlierhood of R.R. Trammen v. Jacksonville Terminal Co., 394 U.S. 369, 383 (1969). The Court has held, however, that it can look to the NLRA "for assistance in construing the Railway Labor Act." Id.

79. 374 U.S. 74 (1963). 
Missouri to invoke the King-Thompson Act. ${ }^{80}$ The Act defined certain public utilities as "life essentials of the people" and outlawed strikes in these industries.81 In denying the state authority to implement this "emergency legislation," the Court found that Congress had preeinpted the state statute by passing the NLRA.82

The facts of Division 988 and of Division 1287 are analogous to those in United Transportation Union, in which the Court of Appeals for the Second Circuit enjoined a strike by railroad employees. ${ }^{83}$ In each case the state government acted to prevent a strike by invoking state law. The Court of Appeals for the Second Circuit in United Transportation Union found that the Taylor Law embodied a legislative policy to protect the public from strikes by public employees. ${ }^{84}$ Similarly, in Division 988 the Supreme Court found that the Wisconsin statute was a comprehensive labor code designed to prevent interruptions in "essential" public services. ${ }^{85}$

Several additional considerations, however, undermine the precedential value of Division 988 and Division 1287. First, in both of these cases the state sought to regulate a service provided by the private sector. In United Transportation Union, a governmental agency operated the transit system on a daily basis in order to implement long-range state policies. The state legislation in Division 988 and Division 1287 sought only to prevent interruptions of privately operated services that the state legislature deemed essential. ${ }^{86}$ More importantly, Usery and the cases following it add a second step to the analysis-a determination whether the federal statute in question "directly displace[s] the
80. Mo. Rev. STAT. $\$ \S 295.010-.210$ (1969).
81. Mo. Rev. STAT. \& 295.010 (1969) provided:
It is hereby declared to be the pohicy of the state that heat, light, power, sanitation, trans- portation, communication, and water are life essentials of the people; that the possibility of labor strife in utilities operating under governmental franchise or permit or under governmental ownership and control is a threat to the welfare and health of the people ....

Mo. REv. STAT. $§ 295.200$ par. 1 (1969) provided:

It shall be unlawful for any person, employee, or representative as defined in this chapter to call, incite, support or participate in any strike or concerted refusal to work for any utility or for the state after any plant, equipinent or facility has been taken over by the state under this chapter, as means of enforcing any deinands against the utility or against the state.

82. 374 U.S. at 82. The Court enphasized that collective bargaining and the right to strike lay at the heart of the federal labor relations scheme.

83. United Transp. Union v. Long Island R.R., 634 F.2d 19 (2d Cir. 1980), cert. granted, 101 S. Ct. 3107 (1981). See notes 61-72 infra and accompanying text.

84. $634 \mathrm{~F} .2 \mathrm{~d}$ at 25 .

85. See note 78 supra.

86. In Division 1287, the Court noted that its decision did not affect the states' right to own or operate a public utility or other business. 374 U.S. at 83 . 
State's freedom to structure imtegral operations."87 In Division 988 and Division 1287, the Court analyzed the state statutes under the supremacy clause and did not consider tenth amendment challenges to the applicability of the federal statutes.

\section{Prior Supreme Court Treatment of STATE-OPERATED Freight RaILroadS}

In applying federal labor legislation to state-operated freight railroads, the Supreme Court has imphed that a state may waive its Usery status. In Usery itself the plurahity cited with approval ${ }^{88}$ the case of United States v. California, ${ }^{89} \mathrm{~m}$ which the Court rejected the state's argument that its sovereign status precluded the application of federal railway safety legislation. ${ }^{90}$ In United States $v$. California the Court held that the State Belt Railroad, though its tracks lay entirely within the San Francisco area, satisfied all the basic criteria of an interstate rail carrier.91 By engaging in imterstate commerce, California "had subjected itself to the commerce power." 92

In California v. Taylor ${ }^{93}$ the State Belt Railroad claimed that state civil service laws protected it from the application of the RLA. ${ }^{94}$ The Supreme Court rejected the state's immunity claim, reasoning that Congress had phrased the RLA's coverage in all-embracing terms. ${ }^{95}$ Relymg on United States $v$. California, the Court emphasized that ex-

87. National League of Cities v. Usery, 426 U.S. 833, 852 (1976).

88. Id. at 854 n.18 (1976). Justice Rehnquist did, however, dismiss dicta in United States v. California, 297 U.S. 175 (1936), which indicated that states stand on similar footing when challenging the exercise of Congress' power to regulate cominerce as "simply wrong." 426 U.S. at 85455.

89. 297 U.S. 175 (1936).

90. Id. at 183. Congress had used its power under the commerce clause to enact the regulation in question, the Safety Appliance Act, 45 U.S.C. $\$ \S 1-46$ (1976).

91. Cahifornia owned and operated the State Belt Railroad whose tracks paralleled the San Francisco waterfront. The line served approximately 175 plants, had connections with four interstate carriers, and carried traffic bound for other states. 297 U.S. at 181-82. The state einphasized that it operated the line "without profit, for the purpose of facilitating the commerce of the port, and [used] the net proceeds of operation for harbor improvements." Id. at 183.

92. Id. at 185. The Court emphasized that the danger of a defective appliance was as great in a state-owned railroad as in a privately-owned line.

93. 353 U.S. 553 (1957).

94. Id. at 559-65.

95. Id. at 562-66.

The fact that Congress chose to phrase the coverage of the Act in all-embracing terms indicates that state railroads were included within it. In fact, the consistent congressional pattern in railway legislation . . . [has been] to employ all-inclusive language of coverage with no suggestion that state-owned railroads were not included.

Id. at 564 . 
clusion of state employees was inconsistent with the national purpose of the RLA. ${ }^{96}$

In Parden v. Terminal Railway ${ }^{97}$ the Court held that a state waives its immunity from suit by engaging in activities covered by the Federal Employers' Liability Act (FELA). ${ }^{98}$ Like the Long Island and State Belt Railroads, the Terminal Railway served only a small area within one state, Alabama.99 The Court compared the FELA with the Safety Apphance ${ }^{100}$ and Railway Labor Acts and determined that state immunity from suit would effectively create a right under the FELA without a remedy. ${ }^{101}$ Alabama argued that under the eleventh amendment, ${ }^{102}$ a state cannot be sued without its consent. ${ }^{103}$ The Court recognized this primciple, but held that the state had consented to potential suits by engaging in activities subject to congressional regulation. ${ }^{104}$

These cases imply that states may consent to some types of federal regulation by providing services that are subject to congressional regulation under the commerce power. A waiver theory appears appropriate in the context of the eleventh amendment, but seems mappropriate in determining state amenability to federal regulation under the commerce power. The validity of this waiver theory depends on the strength of the analogy between the states' eleventl amendment immu-

96. 'We can perceive no reason for extending [the presumption that a statute does not restrict a constituent sovereign state unless it expressly so provides] so as to exempt a business carried on by a state from the otherwise applicable provisions of an act of Congress, all-embracing in scope and national in its purpose, which is as capable of being obstructed by state as by individual action.'

Id. at 562-63 (quoting United States v. California, 297 U.S. 175, 186 (1936)).

97. 377 U.S. 184 (1964).

98. 45 U.S.C. $\$ \S 51-60$ (1976). FELA section 51 provides that "[e]very common carrier by railroad while engaging in commerce between any of the several States . . . shall be liable in damages to any person suffering injury while he is employed by sucl carrier in such commerce." Id. $\$ 51$.

99. Alabama wholly owned and operated the Terminal Railway, which served the docks and several mdustries in the Mobile area. The line operated as an interchange with several privately owned railroads. It performed its services for profit under statutory authority authorizing it to operate "as though it were an ordinary common carrier." ALA. CoDE \& 33-1-16 (1975) (quoted in Parden v. Terninal Railway, 377 U.S. 184, 185 (1964)).

100. Ch. 196, 27 Stat. 943 (1893) (codified in scattered sections of 45, 49 U.S.C.), discussed in United States v. Califorma, 297 U.S. 175 (1936).

101. 377 U.S. at $189-90$.

102. U.S. Const. amend. XI. The eleventh amendinent provides that: "The Judicial power of the United States shall not be construed to extend to any suit in law or equity, commenced or prosecuted against one of the United States by Citizens of another State, or by Citizens or Subjccts of any Foreign State."

103. 377 U.S. at 186.

104. Id. at 190-93. See also Public Serv. Co. v. Federal Energy Regulatory Comm'n, 587 F.2d 716, 720-21 (5th Cir.), cert. denied, 444 U.S. 879 (1979) (state-operated oil and gas business is not a "traditional governmental function"; its operation therefore waives objection to federal regulation). 
nity from suit, ${ }^{105}$ and the states' tenth amendment immunity frone the commerce power. ${ }^{106}$ Although the eleventh amendment explicitly excludes from the judicial power suits against states by citizens of other states, the Constitution lacks any similarly explicit limitation on the commerce power. At most, the tenth amendment merely implies an affirmative limitation on congressional power under the commerce clause.

From a practical standpoint, a waiver theory could lead to the anomolous result that some aspects of a state activity may be subject to regulation while others are not, depending only on whether the activity began before or after the regulation took effect. ${ }^{107}$ More fundamentally, a waiver theory ignores what should be the essential imquiry in determining the applicability of federal regulation to the states-the relative strengths of the state and federal interests involved. 108 As a result, the waiver theory is simultaneously too broad and too narrow, potentially allowing federal regulation where state interests predominate or forbidding federal regulation when the converse is true. Such a theory dictates a static view of governmental services, a view the Supreme Court has condemned. ${ }^{109}$

105. See Edelman v. Jordan, 415 U.S. 651 (1974); Employees of Dep't of Pub. Health \& Welfare v. Dep't of Pub. Health \& Welfare, 411 U.S. 279 (1973). See also Peel v. Florida Dep't of Transp., 600 F.2d 1070 (5th Cir. 1979) (neither tenth nor eleventh amendment prevents a federal court from ordering a state agency to reinstate a former employee under the Veteran's Reemployment Rights Act, 38 U.S.C. $\$ \$ 2021-2026$ (1976), which was passed pursuant to the congressional war power).

106. See Note, Impact of an Essentiality Test, supra note 11, at 173. Compare U.S. ConST. amend. XI ("The Judicial Power of the United States shall not be construed to extend to any suit in law or equity, commenced or prosecuted against one of the United States by Citizens of another State, or by Citizens or Subjects of any Foreign State") with Id. amend. X ("The powers not delegated to the Umited States by the Constitution, nor prohibited by it to the States, are reserved to the States respectively, or to the people").

107. For example, suppose an unincorporated residential area einploys a private security force. A nearby nunicipality annexes the area and incorporates the private force into its inunicipal police department. Federal regulations such as the NLRA and FLSA would cover these workers while employed in the private sector. If a waiver theory were valid, these regulations would continue to apply to that division of the municipal police which had constituted the private force but would not apply to those policemen who had always bcen employed by the city.

108. See notes $136-41$ infra and accompanying text.

109. See New York v. United States, 326 U.S. 572 (1946). See notes 130-35 infra and accoinpanying text. 


\section{Supreme Court Treatment of State Immunity from the TAX Power: Basis for a Proposed ANAlysis OF USERY PROBLEMS}

\section{A. The Governmental-Proprietary Distinction in Tax Immunity Cases.}

In attemptimg to clarify the meaning of an imtegral state function in Usery, Justice Rehnquist suggested that the imtergovernmental tax immunity cases provide a useful analogy. ${ }^{110}$ Similarities between the commerce power and the tax power abound. Both are plenary powers delegated to Congress in article I, section 8 of the Constitution. ${ }^{111}$ Both are limited only by notions of state sovereignty imphed from the tenth amendment. ${ }^{112}$ Although some writers have criticized the analogy between the two powers, ${ }^{113}$ both $U$ sery and the tax immunity cases address the problem of reconciling federal plenary powers with the states' role in a federal system. Thus, the historic development of a standard for determining the reach of the federal tax power as applied to state functions aids in determining limits on the commerce power.

In Collector v. Day ${ }^{114}$ the Court for the first time examined the limits on the scope of a congressional plenary power as applied to the states. A Massacliusetts probate officer argued that his salary was immune from federal income tax. ${ }^{115}$ He contended that a state judicial officer is "a means or instrnmentality employed to carry into execution one of [the state's] most important functions, the administration of the laws." 16 He then argned that his salary was inseparable from his office. In refusing to apply the tax, the Court emphasized the importance of preserving the separate and mdependent status of states as it existed

110. National League of Cities v. Usery, 426 U.S. 833, 843-44 (1976). See New York v. United States, 326 U.S. 572, 582 (1946) ("[s]urely the power of Congress to lay taxes has imphiedly no less a reach than the power of Congress to regulate commerce.")

111. U.S. CoNST. art. I, $\$ 8$.

112. See Massachusetts v. United States, 435 U.S. 444,455 (1978) ("the States' immunity from federal taxes was judicially implied from the States' role in the constitutional scheme"); National League of Cities v. Usery, 426 U.S. 833, 843 (1976) ("The [Tenth] Amendment expressly declares the constitutional policy that Congress may not exercise power in a fashion that impairs the States' integrity or their ability to function effectively in a federal system'") (quoting Fry v. United States, 421 U.S. 542, 547 n.7 (1975)).

113. Compare Note, National League of Cities, Crashes on Takeoff, supra note 11, at 836-39 (examination of tax power cases is "legitimate and useful") with Bogen, supra note 14, at 768-71 (analogy to the tax power is inadequate) and Comment, supra note 11, at 165 and Note, New Approach, supra note 11, at 480-81.

114. 78 U.S. (11 Wall.) 113 (1871), overruled, Graves v. New York ex rel. O'Keefe, 306 U.S. 466 (1939).

115. 78 U.S. at $122-23$.

116. Id at 126 . 
at the time of the Constitution's adoption. ${ }^{117}$ Although the Court later overruled Day's result, it has never repudiated the decision's underlying concerns. ${ }^{118}$

In South Carolina v. United States 119 the Court introduced the distinction between proprietary and governmental state functions. In challenging the applicability of a federal liquor license tax to state liquor dealers, South Carolina argued that it was exercising its sovereign power in operating a liquor business. ${ }^{120}$ The Court upheld the tax, but in doing so acknowledged that the federal government may not "prevent a State from discharging the ordinary functions of government."121

After considering the implications of extensive public ownership on the federal tax power, ${ }^{122}$ the Court sought to accommodate both the federal and state interests. In determining which state functions were immune froun the tax power, the Court sought to preserve certain "governmental" activities, looking primarily "at the Constitution in the hight of the conditions surrounding at the time of its adoption." ${ }^{123}$ The Court distinguished these activities from "proprietary" functions, those services implemented by agencies "which are used by the State in the

117. [T] he means and instrumentalities employed for carrying on the operations of their governments, for preserving their existence, and fulfilling the high and responsible duties assigned to them in the Constitution, should be left free and unimpaired, should not be liable to be crippled, much less defeated by the taxing power of another government, which power acknowledges no limits but the will of the legislative body imposing the tax .... Without this power [to create a judicial department], and the exercise of it, we risk nothing in saying that no one of the States under the form of government guaranteed by the Constitution could long preserve its existence.

Id. at $125-26$.

118. In overnuling Day, the O'Keefe Court found that a tax imposed on a state employee's salary did not sufficiently burden his function to warrant immunity. Graves v. New York ex rel. O'Keefe, 306 U.S. 466, 486-87 (1939).

119. 199 U.S. 437 (1905).

120. Id. at $440-43$.

121. Id. at 451 . Foreshadowing the concern over an unnecessarily restrictive view of state government later expressed by the Court in New York v. United States, 326 U.S. 572, 579 (1946), the South Carolina Court recognized the growing movement "in favor of the acquisition and management by the public of what are termed public utilities, mcluding not merely therein the supply of gas and water, but also the entire railroad system." 199 U.S. at 454.

122. Obviously, if the power of the State is carried to the extent suggested, and with it is rehef from all Federal taxation, the National Government would be largely crippled in its revenues. Indeed, if all the States should concur in exercising their powers to the full extent, it would be almost impossible for the Nation to collect any revenues. In other words, $m$ this indirect way it would be within the competency of the States to practically destroy the efficiency of the National Government. ... .

There is something of a conflict between the full power of the Nation in respect to taxation and the exemption of the State from Federal taxation in respect to its property and a discharge of all its functions.

199 U.S. at $455-56$.

123. Id at 457 . 
carrying on of an ordinary private business."124 Finding that South Carolina's liquor business was "proprietary," the Court held that the federal government could tax the state agents. ${ }^{125}$

The Court had difficulty applying the governmental-proprietary distinction used in South Carolina to subsequent tax immunity cases. ${ }^{126}$ Professors Wells and Hellerstein have argued that these cases deinon-

124. Id. at 461 ; see id. at $458-63$.

[T]here is a clear distinction as respects responsibility for negligence between the powers granted to a corporation for governmental purposes and those in aid of private business, a like distinction may be recognized when we are asked to limit the full power of imposing excises granted to the National Government by an implied inability to impede or einbarrass a State in the discharge of its functions. It is reasonable to hold that while the former may do nothing by taxation in any form to prevent the full discharge by the latter of its governmental functions, yet whenever a State engages in a business which is of a private nature that business is not withdrawn from the taxing power of the Nation.

Id. at 463.

125. Id. at 463 .

126. See, e.g., Helvering v. Gerhardt, 304 U.S. 405 (1938) (tax on New York Port Authority employees does not place an unconstitutional burden on the states); Allen v. Regents of the Univ. Sys., 304 U.S. 439, 453 (1938) (federal tax on admission to state university athletic events does not unconstitutionally burden a state's governmental function: "the immunity implied fron the dual sovereignty by the Constitution does not extend to business enterprises conducted by the States for gain"); Helvering v. Powers, 293 U.S. 214 (1934) (salaries of trustees of inunicipal street railway held not exempt from federal income tax); Ohio v. Helvering, 292 U.S. 360, 369 (1934) (upholding a $\operatorname{tax}$ on state-owned and operated liquor business; in dismissing the state's argument that the police power is elastic, the Court stated: "[w]hen a state cnters the market place seeking customers it divests itself of its quasi sovereignty pro tanto, and takes on the character of a trader, so far, at least, as the taxing power of the federal government is concerned"); Willcuts v. Bunn, 282 U.S. 216, 225 (1931) (municipal bond sale held subject to federal tax because there was no "direct burden" on a governmeut instrumentality and only a "reinote" influence on exercise of government functions); Metcalf \& Eddy v. Mitchell, 269 U.S. 514, 524 (1926) (federal tax applies to state employees unless the state agency is "of such a character or so intimately counected witli the exercise of a power or the performance of a duty by the one government, that any taxation of it by the other would be such a direct interference with the functions of government itself as to be plainly beyond the taxing power').

In Gerhardt the Court held that any constitutional restriction on Congress's taxing power should be narrowIy limited. 304 U.S. at 416 . The Court recognized the steady expansion of state governments into new fields but concluded that the activity in question was not essential to the preservation of state governmental powers. Id. at 416-17, 419. The Court then appeared to balance the federal and state interests. Id. at 419. In attempting to establish guidelines for the balancing test, Justice Stone argned that the quantitative impact of the tax must be "actual and substantial, not conjectural." Id. at 421. Having concluded that the burden was speculative, he expressed no opinion about "whether a federal tax may be imposed upon the Port Authority itself with respect to its receipt of income or its other activities." Id. at 424.

In Powers the Court determined that a street railway was not a governmental state function and applied a balancing test to determine the tax's validity. The trustees argued that the Supreme Judicial Court of Massachusetts had characterized the railway as a "public operation" "undertaken by the Commonwealth not as a source of profit but solely for the general welfare." 293 U.S. at 222. Unpersuaded, the Court stated:

We see no reason for putting the operation of a street railway in a different category from the sale of liquors. In each case, the State, with its own conception of public advantage, is undertaking a business enterprise of a sort that is normally within the reach of the federal taxing power and is distinct from the usual governmental functions that are 
strate that the governmental-proprietary distinction lacks solid analytical justification; ${ }^{127}$ in their view, the distinction serves as a vehicle to circumscribe potentially unlimited state immunity. ${ }^{128}$ Their criticism centers not on the need for soine distinction immunizing certain state activities from federal regulation, but on the type of distinction chosen by the Court. 129

In New York v. United States ${ }^{130}$ the Court rejected the governmental-proprietary distinction as a tool to analyze tax immunity problems. This distmction, Justice Frankfurter wrote, was "too shifting a basis for determining constitutional power and too entangled in expediency to serve as a dependable legal criterion."131 Claiming immunity from a federal tax on the sale of mineral water, New York argued that its mineral water business was "a usual, traditional and essential governmen-

immune from federal taxation in order to safeguard the necessary independence of the State.

Id. at 227.

Post-Usery courts have encountered similar difficulties. See, e.g., United Transp. Union v. Long Island R.R., 634 F.2d 19 (2d Cir. 1980), cert. granted, 101 S. Ct. 3107 (1981); Amersbach v. City of Cleveland, 598 F.2d 1033 (6th Cir. 1979); Friends of the Earth v. Carey, 552 F.2d 25 (2d Cir.), cert. denied, 434 U.S. 902 (1977); Alewine v. City Council, 505 F. Supp. 880 (S.D. Ga. 1981).

In Amersbach a panel of the Court of Appeals for the Sixth Circuit suggested a four-pronged test for classifying essential state functions:

(1) The government service or activity benefits the community as a whole and is available to the public at little or no direct expense;

(2) The service or activity is undertaken for the purpose of pubhe service rather than for pecuniary gain;

(3) Government is the principal provider of the service or activity; and

(4) Government is particularly suited to provide the service or perform the activity because of a communitywide need for the service or activity.

\section{$598 \mathrm{~F} .2 \mathrm{~d}$ at 1037.}

In Alewine the court found the Amersbach criteria unpersuasive. The district judge suggested that the first requirement-that the service is available to the public at "little or no direct expense"--seemed contrary to one of the examples mentioned by the Supreme Court in Useryhospitals. The Alewine court, using the synonyun "integral operation" for essential function, defined it as one "which the public has come to expect and demand in hight of the change of times and needs of society." 505 F. Supp. at 889.

127. Wells \& Hellerstein, supra note 14 , at 1083-84.

128. Id.

129. Like the type of distinction that this comment proposes, see notes I36-39 infra and accompanying text, the governmental-proprietary distinction used by the Sourth Carolina Court does not provide blanket protection for any service. Rather, the proposed analysis allows the Supreme Court to apply a balancing test to determine when an activity is "sufficiently important to a state's identity to warrant restriction of the Federal taxing power." Id. at 1084 .

130. 326 U.S. 572 (1946).

131. Id. at 580 (Frankfurter, J., announcing the judgment of the Court, joined by Rutledge, J.). Other justices held similar views. Id. at 589 (Stone, C.J., concurring, joined by Reed, Murplry, and Burton, J.J.) ("[t]he problem [of tax immunity] is not one to be solved by a formula, but we may look at the structure of the Constitution as our guide to decision'); id. at 591 (Douglas, J., dissenting, joimed by Black, J.) ("[a] State's project is as much a legitimate governmental activity whether it is traditional, or akin to private enterprise, or conducted for profit"). 
tal function."132 In rejecting this claim, the court found that the governmental-proprietary distinction unjustifiably and artificially curtailed the federal taxing power. ${ }^{133}$

The justices' analyses, however, suggest that they rejected only this particnlar distinction, not the general need for solne distinction measuring the susceptibility of various state functions to federal taxation. All members of the Court agreed that the taxability of a state activity should not depend solely on whether it was conducted by the states in 1787: "Such a static concept of government denies its essential nature." 134 But six justices agreed that some state activities were not imnuune froin the federal tax power. ${ }^{135}$

\section{B. A Proposed Analytical Framework.}

The tax-immunity cases suggest a balancing formula im which the historic nature of the governmental function plays an important but not decisive role cases. When a fcderal tax (or the exercise of federal power under the commerce clause) interfercs with a governmental

132. Id at 574.

133. Id. at 583-84 ("we reject limitations upon the taxing power of Congress derived from such untenable criteria as 'proprietary' against 'governmental' activities of the States, or historically sanctioned activities of government or activities conducted merely for profit, and find no restriction upon Congress to include the States in levying a tax exacted equally from private persons upon the same subject matter") (footnote omitted); id. at 589 (Stone, C.J., concurring, jomed by Reed, Murphy, and Burton, J.J.) ("It]he national taxing power would be unduly curtailed if the State, by extending its activities, could withdraw from it subjects of taxation traditionally within it").

134. Id at 579 (Frankfurter, J., announcing the judgment of the Court) (remarking on "the vast extension of the sphere of government, both State and National, compared with that with which the Fathers were familiar. It could hardly remain a satisfactory constitutional doctrine that only such State activities are immune from federal taxation as were engaged in by the States in 1787'). See also id. at 588-90 (Stone, C.J., concurring). Chief Justice Stone suggested that the nature and extent of the state activity in question were not the determinative considerations and exphcitly recognized the utility of a balancing formula. Id. at 589-90. Justice Douglas, dissenting, argued that the states, by undertaking the activity, had removed the project from the scopo of the tax power:

A State's project is as inuch a legitimate governmental activity whether it is traditional, or akin to private enterprise, or conducted for profit. A State may deem it as essential to its econouny that it own and operate a railroad, a mill, or an irrigation system as it does to own and operate bridges, street hights, or a sewage disposal plant. What might have been viewed in an earlier day as an improvident or even dangerous extension of state activities may today be deemed indispensable.

Id at 591 (Douglas, J., dissenting, joimed by Black, J.) (citations omitted).

135. Id at 575-80, 582 (Frankfurter, J., announcing the judgment of the Court). But see id. at 586 (Stone, C.J., concurring) ("we are not prepared to say that the national government may constitutionally lay a non-discriminatory tax on every class of property and activities of State and individuals alike'). In his dissent Justice Douglas argued that the federal government should not tax any state governmental activity. Id. at 590-98 (Douglas, J., dissenting, joined by Black, J.). 
function that was exercised in $1787,{ }^{136}$ the federal government ordinarily bears a heavy burden of showing that the interference is necessary to the federal taxation scheme or that it does not unduly interfere with the state function. ${ }^{137}$ When, however, the federal tax burden falls on a governmental activity instituted after the drafting of the Constitution, such as the sale of mineral water, the state has the burden of showing that the federal tax amounts to "undue interference."138 In determining whether a federal regulation under either the tax or commerce power is an "undue interference," the court inust consider the importance of the activity to the state and the degree to which the federal regulation frustrates that activity. ${ }^{139}$

This proposed framework uses terminology similar to that used on different occasions by the Supreme Court. ${ }^{140}$ Unlike the Court's various renditions, however, this framework assigns distinct meanings to the terms "traditional" and "essential" and uses the terms consistently. Furthermore, by considering more than merely whether a state function is traditional, this framework averts the "static concept of goverument" criticized by the Court. ${ }^{141}$

The result reached by the court in the most recent tax immunity case, Massachusetts $v$. United States, ${ }^{142}$ is in accord with this analytical framework. Massachusetts claimed immunity from a registration tax

136. The reason for attaching significance to the year the Constitution was drafted is that the government functions performed by the states on that date are most clearly those which the framers imtended to insulate from federal imterference. See id. at 579; South Carolina v. United States, 199 U.S. 437, 457-58 (1905); Collector v. Day, 78 U.S. (11 Wall.) 113, 126 (1871), overruled, Graves v. New York ex. rel. O'Keefe, 306 U.S. 466 (1939).

137. Cf. National League of Cities v. Usery, 426 U.S. 833, 856 (1976) (Blackmun, J., concurring) (plurality approach "does not outlaw federal powers in areas . . . where the federal interest is demonstrably greater and where state facility comphance with imposed federal standards would be essential"').

138. See Massachusetts v. Umited States, 435 U.S. 444, 459 (1978).

139. See Reeves, Inc. v. Stake, 447 U.S. 429 (1980). The Court has implicitly recognized that the importance a state attaches to a particular state activity or regulation differs with individual state policies. Compare id. (a Wyoming concrete distributor unsuccessfully challenged a South Dakota policy which required a state-owned cement plant to sell only the amount of concrete exceeding in-state demand to out-of-state customers) with Hicklin v. Orbeck, 437 U.S. 518 (1978) (Alaska Law requiring that qualified Alaska residents be hired in preference to non-residents held violative of the privileges and immunities clause of the Constitution). In Hicklin the Court also stated that "the Commerce Clause circumscribes a State's ability to prefer its own citizens in the utilization of natural resources found within its borders but destined for interstate commerce." Id. at 533 .

140. See New York v. Umited States, 326 U.S. 572, 579 (1946).

141. Id.

142. 435 U.S. 444 (1978). Justice Breman delivered the opimion of the Court in which Justices White, Marshall, and Stevens joined. Concurring in the judgment, Justices Stewart and Powell found no need to discuss the general contours of state immunity from federal taxation. Id. at 47071. Jnstice Rehnquist and Chief Justice Burger dissented. Id. at 471. 
on aircraft owned by the state and used exclusively for police functions. ${ }^{143}$ Under the proposed analytical sclieme, the federal government would bear the burden of proving that the registration tax was either part of a comprehensive federal scheme or that the tax did not unduly restrict the state's police activity. Writing for the majority, Justice Brennan concluded that Congress regarded the tax "as an integral and essential part of the network of user charges." 144 In discussing the scope of state immunity froin fcderal taxation, Justice Brennan distimguished between taxes imposed on different governmental functions. ${ }^{145}$ The proposed framework suggests that to tax traditional activities the federal government must slow that its interest demonstrably exceeds the state interest. But when the federal government imposes a tax on an essential state function, the state bears the burden of proving undue interference witl state activity. ${ }^{146}$ Applying the " "practical construction' that the Court now gives to the limitation the existence of the states constitutionally imposes on the national taxing power," 147 Justice Brennan concluded that the increased cost imposed by the registration tax did not unduly interfere with Massachusetts's activity. ${ }^{148}$

\section{INTERgOVERNMENTAL IMMUNITY UNDER THE COMMERCE POWER: CONSTITUTIONAL AND STATUTORY ANALYSIS OF STATE EXEMPTION FROM THE SHERMAN ANTITRUST ACT}

The Supreine Court's treatment of state immunity from the Sherman Antitrust Act ${ }^{149}$ illustrates the concept of a shifting burden of proof as well as the role of statutory interpretation in applying a fedcral

143. Id. at 446. Congress imposed the registration tax on all civil aircraft that fly in the navigable airspace of the United States. 26 U.S.C. $\$ 4491$ (1976).

144. 435 U.S. at 451 . Justice Brennan noted that the registration tax was "the only tax imposed on those general noncommercial aircraft owned and operated by States." Id. at 452.

145. As the contours of the principle [of state immunity] evolved in later decisions, "cogent reasons' were recognized for narrowly limiting the immunity of the States froln federal imposts. The first is that any immunity for the protection of state sovereignty is at the expense of the sovereign power of the National Government to tax. Therefore, when the scope of the States' constitutional immunity is enlarged beyond that necessary to protect the continued ability of the States to deliver traditional governmental services, the burden of the immunity is thrown upon the National Government without any corresponding promotion of the constitutionally protected values.

Id. at 456 (citations omitted) (eniphasis added).

146. The Court "has recognized that some generic types of revenue measures could never seriously threaten the continued functioning of the States and hence are outside the scope of the impled tax immunity." Id. at 460.

147. Id. at 459.

148. Id. at $467-69$.

149. 15 U.S.C. $\$ \$ 1-7$ (1976). 
statute to a particular state function. ${ }^{150}$ In Parker v. Brown ${ }^{151}$ the Supreme Court held that federal antitrust law did not preempt a California statute that established a regulatory nechanism allowing local raisin growers to maintain prices "so as to restrict competition among the growers."152 The Court assumed that the activity the California statute allowed would violate the Sherman Act if it were an undertaking by private parties rather than by the state of California. ${ }^{153}$ Nevertheless, the Court upheld the statute, finding that Congress intended the Sherman Act not to apply to action directly involving a state's regulatory machinery. ${ }^{154}$ Apparently, the Court assumed that Congress could have made the Act applicable to such state action. ${ }^{155}$

The Parker Court's inquiry differs from that of the Usery Court in an important respect. The Parker Court examined whether the specific action attacked was an official act of the state. ${ }^{156}$ The $U_{\text {sery }}$ Court asks additionally whether the federal regulation forces "directly upon the states [Congress's] choices as to how essential decisions regarding the conduct of integral govenmental choices are to be inade."157 The Parker Court never reached this question.

In Parker the Court emphasized that the history of the state function involved was relevant in determining whether the state activity fell within the purview of the Sherman Act. Citing Northern Securities Co. v. United States, ${ }^{158}$ the Parker Court reasoned that states could not sanction a private price-fixing agreennent. In Northern Securities the petitioners had argued that their corporate acts were immune from the

150. See generally Davidson \& Butters, Parker and Usery: Portended Constitutional Limits on the Federal Interdiction of Anticompetitive State Action, 31 VAND. L. REv. 575 (1978); Slater, Antitrust and Government Action: A Formula for Narrowing Parker v. Brown, 69 Nw. U.L. REv. 71 (1974); Comment, The Erosion of State Action Immunity from the Antitrust Laws: City of Lafayette v. Louisiana Power \& Light Co., 45 BRookLYN L. REv. 165 (1978); Note, Federal Antitrust Immunity: Exposure of Municipalities to Treble Antitrust Damages Sets Limit for New Federalism: City of Lafayette v. Louisiana Power \& Light Co., 11 ConN. L. Rev. 126 (1978); Comment, National League of Cities and the Parker Doctrine: The Status of State Sovereignty Under the Commerce Clause, 8 FORDHAM URB. L.J. 301 (1980).

151. 317 U.S. 341 (1943).

152. Id at 346.

153. Id at 350 .

154. Id. at 350-52. "There is no suggestion of a purpose to restrain state action in the Act's legislative history. The sponsor of the bill which was ultimately enacted as the Sherman Act declared that it prevented only 'business combinations.' "Id at 351 (citations omitted). But see City of Lafayette v. Louisiana Power \& Light Co., 435 U.S. 389, 39497 (1978) (discussed at notes 177-90 infra and accoinpanying text).

155. 317 U.S. at 350-51. See Comment, The Status of State Sovereignty, supra note 150, at 313.

156. 317 U.S. at $350-52$.

157. National League of Cities v. Usery, 426 U.S. 833, 855 (1976).

158. 193 U.S. 197 (1904). 
Sherman Act because their acts were consistent with their state corporate charter. ${ }^{159}$ In rejecting this defense, Justice Harlan imphicitly balanced the federal interest embodied in the Sherman Act agaimst the state's traditional interest in chartering corporations. ${ }^{160}$

In determining that certain state activities are not prohibited by the Sherman Act, the Parker Court cited with approval Lowenstein v. Evans. ${ }^{161}$ The Lowenstein court held South Carolina's liquor monopoly exempt from antitrust legislation and observed:

The state is a sovereign having no derivative powers, exercising its sovereignty by divine right. . . . It has bound itself by compact with the other sovereign states not to exercise certain of its sovereign rights, and has conceded these to the Umion, but in every other respect it retains all its sovereignty which existed anterior to and independent of the Union. ${ }^{162}$

A comparison of Lowenstein and South Carolina v. United States ${ }^{163}$ illustrates the importance in an Usery analysis of the scope of the federal statute in question. In Lowenstein the court implicitly found that the Sherman Act was not intended to regulate essential state activities that actively involve the state. In South Carolina v. United States the Court held that the application of a federal tax to state agents engaged in the sale of liquor did not "impede or einbarrass a State in the discharge of its functions." 164 The Court inferred that Congress's comprehensive approach to levying the tax evinced a strong federal interest and this inference played a key role in determining the statute's applicability to the state function. The comparison thus suggests that a definitional approach to determining the state activities that Congress can preempt does not suffice; the Court must balance the state interest in providing a particular service and the federal interest in regulating that service.

The Parker Court's analysis comports with that of the proposed Usery framework, which would shift the burden of proving a Sherman Act exemption to the state that attempts to protect essential, as opposed to traditional, governmental activities. Chief Justice Stone, writing for the inajority, distinguished a state statute that merely permits private anticompetitive behavior from a state statute that actively involves the state in impairing the Sherman Act policy of pronnoting a free market

159. Id. at 344-45.

160. Id. at 345-52.

161. 69 F. 908 (C.C.D.S.C. 1895).

162. Id. at 911 .

163. 199 U.S. 437 (1905). See notes 119-25 supra and accompanying text.

164. 199 U.S. at 463. 
economy. ${ }^{165}$ The Sherman Act preempts the former state statute, but permits the latter as a sovereign governmental decision. ${ }^{166}$ Some traditional state activities, such as economic regulation, ${ }^{167}$ escape the Sherman Act because the Act is not based on a demonstrably greater federal interest in regulatimg this type of state activity.

Subsequent antitrust decisions involving the Parker doctrine also support the use of the two-tiered analysis proposed in this comment. In Goldfarb v. Virginia State Bar ${ }^{168}$ the Court held the federal antitrust provisions applicable to a minimun fee schedule for lawyers publislied by a county bar association and recommended by the state bar. ${ }^{169}$ The Court recognized the state's traditional function of regulating the bar. Nevertheless, the Court held that the federal interest in the Sherman Act was demonstrably greater than the state's interest in the fee scliedule. ${ }^{170}$ The Court's analysis indicates that traditional state activities do not receive blanket protection from federal regulation; rather, these state functions are rebuttably beyond the purview of federal regulation.

In Bates v. State Bar ${ }^{171}$ the Supreme Court upheld against an antitrust challenge a disciplinary rule prohibiting advertising by lawyers. ${ }^{172}$

165. Parker v. Brown, 317 U.S. 341, 350-52 (1943). The Court noted that the California program involved active state government participation:

It is the state which has created the inachinery for establishing the prorate program. Although the organization of a prorate zone is proposed by producers, and a prorate program, approved by the Commission, inust also be approved by referendum of producers, it is the state, acting through the Commission, which adopts the program and which enforces it with penal sanctions, in the execution of a governmental policy. The prerequisite approval of the program upon referenduin by a prescribed number of producers is not the imposition by them of their will upon the mimority by force of agreeinent or combiation which the Sherman Act prohibits. The state itself exercises its legislative authority in making the regulation and in prescribing the conditions of its application.

The required vote on the referendum is one of these conditions.

Id. at 352. See California Retail Liquor Dealers Ass'n v. Midcal Aluminum, Inc., 445 U.S. 97, 105 (1980); New Motor Vehicle Bd. v. Orrin W. Fox Co., 439 U.S. 96, 109 (1978). See also Davidson \& Butters, supra note 150, at 583-84; Handler, The Current Attack on the Parker v. Brown State Action Doctrine, 76 Colum. L. REv. 1, 14-15 (1976).

166. 317 U.S. at 352.

167. In Munn v. Illinois, 94 U.S. 113 (1876), the Court observed:

[I]t has been customary in England from time immemorial, and in this country from its first colonization, [for the sovereign] to regulate ferries, common carriers, hackmen, bakers, millers, wharfingers, innkeepers, \&c., and in so doing to fix a maximum of charge to be inade for services rendered, accommodations furnished, and articles sold.

Id. at 125.

168. 421 U.S. 773 (1975).

169. Although the Fairfax County Bar Association was a purely voluntary association, the state bar was an administrative agency through which the state supreme court regulated the practice of law in the state. Id. at 776-78. The United States Supreme Court could not identify any state statute or state supreme court rule sanctioning the fee schedule. $I d$. at 790.

170. Id. at 791-93.

171. 433 U.S. 350 (1977).

172. After rejecting the petitioners' antitrust claims, the Court held that the disciplinary rule violated their first amendment rights. Id. at 363-84. 
The Court determined initially that the petitioners' clainı was an attack on the state supreme court, not on a private party. ${ }^{173}$ Distimguishing Goldfarb, Justice Blackmun viewed the Bates disciplinary rule as a "clear articulation of the State's policy with regard to professional behavior." $174 \mathrm{He}$ also emphasized the state's interest in regulating attorney conduct and the historic position of attorneys as officers of the court. ${ }^{175}$ The degree of the state's imvolvement in regulating the attorneys' conduct distimguishes Bates from Goldfarb; the federal interest remained unchanged. The Court thus seemed to apply a two-tiered balancing test in determining whether "federal policy is being unnecessarily and inappropriately subordinated to state policy."176

Both the plurality opinion and Chief Justice Burger's concurrence in City of Lafayette v. Louisiana Power \& Light Co. ${ }^{177}$ reach a result consistent with the proposed analytical framework. In City of Lafayette Louisiana had granted two municipalities authority to own and operate electric utility systems both within and beyond their city limits. ${ }^{178}$ The municipahities brought an antitrust action against the Louisiana Power \& Light Company. When the power company counterclaimed for relief from alleged antitrust violations by the municipal utilities, the cities argued that the Parker doctrine rendered federal antitrust laws inapplicable to thein. ${ }^{179}$

Justice Brennan, writing for the plurahty, rejected the cities' claim of immunity. Justice Brennan initially examined the Shernnan Act's purpose and concluded that Congress intended the Act's definition of "persons" to include both cities and states. ${ }^{180} \mathrm{He}$ then stated that the Court might treat cities less favorably than states in deternning their immunity from federal law. ${ }^{181}$ Unless the state specifically authorizes the city to engage in activity that will violate the Sherman Act, ${ }^{182}$ a city cannot invoke the Parker doctrine. ${ }^{183}$ In City of Lafayette the cities

173. Id. at 361 .

174. Id. at 362 .

175. Id. at 361-62 (quoting Goldfarb v. Virginia State Bar, 421 U.S. 773, 792 (1975)).

176. 433 U.S. at 362 . But see Davidson \& Butters, supra note 150 , at 594-95.

177. 435 U.S. 389 (1978).

178. Id. at 391 .

179. Id. at 392-94.

180. Id. at 394-97. See Georgia v. Evans, 316 U.S. 159, 162 (1942) ("[n]othing in the [Sherman] Act, its history, or its policy, could justify so restrictive a coustruction of the word 'person' in $\$ 7$ as to exclude a State").

181. 435 U.S. at $397-404$.

182. Cf. Parker v. Brown, 317 U.S. 341, 352 (1943) (active state involvement is necessary to exempt private activity from Sherman Act's coverage).

183. City of Lafayette v. Louisiana Power \& Light Co., 435 U.S. 389, 400 (1978); one possible justification for this distinction is that municipalities derive their power from the state. See Hunter v. City of Pittsburgh, 207 U.S. 161, 178-79 (1907). 
were unable to make this showing.

In his concurring opinion Chief Justice Burger expressly recognized the constitutional issue raised by the city's exemption argunent. Usmg the governmental-proprietary terminology rejected by the Court in New York v. United States, ${ }^{184}$ the Chief Justice framed the issue as "whether the Sherman Act reaches the proprietary enterprises of mumicipahties."'185 Citing both commerce and tax power cases ${ }^{186}$ and emphasizing the comprehensiveness of the federal antitrust scheme, ${ }^{187}$ the Chief Justice concluded that "the running of a business enterprise [an electric utility] is not an integral operation in the areas of traditional government functions." 188 Consequently, he found that this kind of municipal activity was not exeinpt from the Sherman Act.

Under the proposed analysis, the municipalities would have failed to prove that the state interest in providing electricity exempt from Sherman Act restrictions was demonstrably greater than the federal interest of promoting economic competition without municipal interference. Justice Brennan, in City of Lafayette, noted the "serious economic dislocation which could result if cities were free to place their own parochial interests above the Nation's economic goals refiected in the antitrust laws." 189 The antitrust laws, moreover, form a comprehensive federal scheme: "Congress, exercising the full extent of its constitutional power, sought to establish a regine of competition as the fundamental principle governing commerce in this country."190

184. 326 U.S. 572 (1946). See notes 130-33 supra and accompanying text.

185. 435 U.S. at 422 . See Community Communications Co. v. City of Boulder, 50 U.S.L.W. 4144, 4147 (U.S., Jan. 13, 1982) (No. 80-1350).

186. 435 U.S. at $422-24$ (citing National League of Cities v. Usery, 426 U.S. 833 (1976) (discussed at notes 21-42 supra and accompanymg text); Parden v. Terminal Ry., 377 U.S. 184 (1964) (discussed at notes 97-104 supra and accompanying text); California v. Taylor, 353 U.S. 553 (1957) (discussed at notes 93-96 supra and accoinpanying text); United States v. California, 297 U.S. 175 (1936) (discussed at notes 89-92 supra and accompanying text); Ohio v. Helvering, 292 U.S. 360 (1934) (discussed in note 126 supra)).

187. 435 U.S. at 424-26.

188. Id. at 424 .

189. Id: at $412-13$.

190. Id. at 398. See United States v. South-Eastern Underwriters Ass'n, 322 U.S. 533, 553 (1944) ("[l]anguage more comprehensive is difficult to conceive. On its face it shows a carefully studied attempt to bring within the Act every person engaged in business whose activities might restrain or monopolize commercial intercourse among the states"). 
VI. Applying the Proposed Framework to the Labor RELATIONS OF MUNICIPALLY OWNED AND OPERATED COMMUTER RAIL SYSTEMS

Analysis under the proposed framework of the labor problems involved im state-operated commuter-freight rail systems indicates that state governments cannot preempt federal labor legislation. Although some courts have asserted that such rail systems perform a local service and do not affect interstate commerce, ${ }^{191}$ the adoption of the Urban Mass Transportation Act (UMTA) ${ }^{192}$ in 1964 demonstrates that the problems of mass transit systems are national in scope. Congress adopted the UMTA in response to the realization that "the welfare and vitality of urban areas [and] the satisfactory movement of people and goods within such areas" depend on mass transportation. ${ }^{193}$ In enacting the legislation, Congress rejected the argument that "mass transportation problems are 'local' and should be a local responsibility." 194

In adopting the UMTA Congress also expressed its concern that transit employees retain the same bargaining rights under public ownership that they enjoyed under private ownership. Section 13(a) of the UMTA requires the Secretary of Transportation to provide funds to a local public body or agency only after a determination by the Secretary of Labor that "fair and equitable arrangements are made . . . to protect the interests of employees affected by such assistance." 195 One

191. E.g., United Transp. Union v. Long Island R.R., 634 F.2d 19 (2d Cir. 1980), cert. granted 101 S. Ct. 3107 (1981); Staten Island Rapid Transit Operating Auth. v. IBEW, Local 922, 57 A.D.2d 614, 393 N.Y.S.2d 773, appeal denied, 42 N.Y.2d 804, 397 N.Y.S.2d 1028, cert. denled, 434 U.S. 934 (1977).

192. 49 U.S.C. $\S \S 1601-1613$ (1976).

193. Id. §1601(a)(2).

194. See H.R. ReP. No. 204, 88th Cong., 1st Sess. 1-4, reprinted in [1964] U.S. CODE CONG. \& AD. NEWS 2569-2572. The House Report also noted: "Mass transportation needs have outstripped the present resources of the cities and States, and a nationwide program can substantially assist [these] problems. . . . The continued economic vitality and growth of our urban areas is essential to our national welfare." Id. at 4, [1964] U.S. CODE CONG. \& AD. NEws at 2573 (emphasis added). But see id. at 22-23, 25-26, [1964] U.S. CoDE CoNG. \& AD. NEws at 2590-2593 (minority views).

195. 49 U.S.C. $\$ 1609$ (c) (1976). Several courts have addressed the related issue of whether a federal court nay enjoin a state government from breaching the provisions of a section 13(c) agreement. Most courts have found jurisdiction to rest in the federal, not the state, judiciary. See Local Div. No. 714, Amalgamated Transit Union v. Greater Portland Transit Dist., 589 F.2d 1, 13-14 (1st Cir. 1978); Local Div. 519, Amalgamated Transit Union v. LaCrosse Mun. Transit Util, 585 F.2d 1340, 1349-50 (7th Cir. 1978); Division 1287, Amalgamated Transit Union v. Kansas City Area Transp. Auth., 582 F.2d 444, 450 (8th Cir. 1978), cert. denied, 439 U.S. 1090 (1979); Division 1287, Amalgamated Transit Union v. Kansas City Area Transp. Auth., 485 F. Supp. 856, 862 (W.D. Mo. 1980); Division 1212, Amalgamated Transit Union v. Chattanooga Area Regional Transp. Auth., 483 F. Supp. 37, $38-39$ (E.D. Tenn. 1979). The UMTA's legislative history also evinces congressional concern over preserving collective bargaining rights for employees of pub- 
commentator has argued, however, that subsequent UMTA amendments not affecting section 13(a) have been "increasingly emphatic in [their] recognition of the essential [i.e., not subject to federal regulation] nature of transportation." 196 Nevertheless, the purpose of the UMTA demonstrates that commuter rail systeins involve national probleins and that their labor problems are subject to the commerce power. ${ }^{197}$

The comprehensiveness of the Railway Labor Act ${ }^{198}$ also implies that the labor problems of lines providing both commuter and freight services present national problems. The RLA establishes a procedure for resolving labor disputes involving railroad workers. ${ }^{199}$ On numerous occasions the Supreine Court has interpreted this scheme as alleinbracing in scope and national in purpose. ${ }^{200}$

The RLA expressly excludes from its coverage "street, imterurban, or suburban electric railway[s]."201 Given the Court's broad interpretation of the RLA, however, the statute's inclusion of "all carriers"202 probably covers lines providing both freight and commuter services. One example of the Court's broad interpretation of the RLA is the holding that the RLA covers state-owned freight lines. ${ }^{203}$ In so holding the Court noted that Congress did not differentiate between privately-

licly acquired transit systems. H.R. REP. No. 204, 88th Cong., lst Sess. 15-16, [1964] U.S. CoDE Cong. \& AD News 2569, 2583-84. But see Adams v. Massachusetts Bay Transp. Auth., No. 79 2059-S (D. Mass., Dec. 24, 1980) (federal jurisdiction improper where subject involved a conflict between section 13(c) agreement and an amended state law); H.R. REP. No. 204, supra, at 28-29, [1964] U.S. Code Cong. \& Ad News 2595-96.

196. Note, Impact of Essentiality Test, supra note 11, at 169. See Urban Mass Transportation Act, 49 U.S.C. $\$ \S 1601 \mathrm{a}, 160 \mathrm{lb}$ (1976).

197. The UMTA does not require that commuter rail employees retain their prior collective bargaining rights. In Alewine v. City Council, 505 F. Supp. 880, 890 (S.D. Ga. 1981), the court noted that federal financial backing does not bear on whether an activity is essential. Usery declared that fire prevention, police protection, sanitation, public health, parks and recreation and school and hospital operations are not subject to the FLSA. See National League of Cities v. Usery, 426 U.S. 833 (1976). The Alewine court observed that the federal government provides financial assistance for inany state services including these services. See 505 F. Supp. at 890 . But see Bogen, supra note 14, at 776-80. See also City of Macon v. Marsliall, 439 F. Supp. 1209 (M.D. Ga. 1977) (by accepting UMTA funds, local governments may be required under the spending power to afford collective bargaining rights to employees).

198. 45 U.S.C. $\$ \$ 151-188$ (1976).

199. Id. $\S \S 152-160$.

200. See Brotherliood of R.R. Trainunen v. Jacksonville Terminal Co., 394 U.S. 369, 380-83 (1969); Brotherhood of R.R. Trainmen v. Chicago River \& Ind. R.R., 353 U.S. 30, 40 (1957); California v. Taylor, 353 U.S. 553, 560-64 (1957).

201. 45 U.S.C. $\$ 151$ (1976).

202. Id. \& 152 .

203. See Brotherlood of R.R. Trainmen v. Jacksonville Terminal Co., 394 U.S. 369 (1969); California v. Taylor, 353 U.S. 553 (1957). Despite these holdings, one commentator has argued that Congress did not intend to affect the labor relations of systems operating a commuter-freight line. Note, Impact of Essentiality Test, supra note 11, at 169-70. 
owned and state-owned rail lines and that the effectiveness of the RLA depends on its application to all rail lines. ${ }^{204}$ The Court has also noted that state-owned railroads were common when Congress passed the RLA. ${ }^{205}$ In the Court's view, had Congress intended to exeinpt stateowned lines, it would not have chosen to define the Act's scope to include all railroads. ${ }^{206}$

The RLA differs froin the National Labor Relations Act (NLRA), which expressly excludes state and local governments froin its definition of covered employers. ${ }^{207}$ In California v. Taylor ${ }^{208}$ the Court distinguished the NLRA froin the RLA on the basis of the former's exclusion clause and the latter's coverage of all common carriers. ${ }^{209}$ The Court emphasized that the RLA seeks "[t]o avoid any interruption to commerce." 210

Attempting to explain Taylor as based on the particular carrier's impact on interstate commerce ignores the broad reach of the coinmerce power. ${ }^{211}$ Moreover, the proposed analysis suggests that the federal and state interests involved will deterinine the RLA's applicability. ${ }^{212}$ Thus, the Taylor Court's emphasis on the RLA's comprehensiveness, a comprehensiveness that evinces a strong federal interest, supports the application of the RLA to commuter rail systems that inamtain soine business in interstate commerce. ${ }^{213}$

204. Brotherhood of R.R. Trainmen v. Jacksonville Terminal Co., 394 U.S. 369, 380-82 (1969); California v. Taylor, 353 U.S. 553, 563-65 (1957).

205. See Helvering v. Powers, 293 U.S. 214 (1934); United States v. Railroad Co., 84 U.S. (17 Wall.) 322 (1873).

206. California v. Taylor, 353 U.S. 553, 564-65 (1957).

207. 29 U.S.C. $§ 152(2)$ (1976) (excluding from coverage "any State or political subdivision thereof"). In NLRB v. Natural Gas Util. Dist., 402 U.S. 600 (1971), the Supreme Court noted that ncither the NLRA nor its legislative history explicitly defines the term "political subdivision." Id. at 604 . Finding that the district was an entity " 'administered by individuals who are responsible to public officials," " the Court concluded that the district was a political subdivision exempt under the NLRA. Id. at 605-09.

208. 353 U.S. 553 (1957).

209. Id at 564 .

210. Id. at 566 (emplasis added).

211. See Katzenbach v. McClung, 379 U.S. 294 (1964); NLRB v. Jones \& Laughlin Steel Corp., 301 U.S. 1 (1937).

212. See notes 136-39 supra and accompanying text.

213. 353 U.S. at $567-68$.

Congress no doubt concluded that a uniforn method of dealing with the labor problems of the railroad industry would tend to eliminate inequities, and would promote a desirable mobility within the railroad labor force. . . . If California, by engaging in interstate commerce by rail, subjects itself to the commerce power so that Congress can make it conform to federal safety requirements, it also has subjected itself to that power so that Congress can regulate its employment relationships.

Id. In the context of rail-safety regulation, the lower courts have disagreed about whether Congress intended to include commuter systems in the Railway Safety Act's coverage, 45 U.S.C. $\$ \$ 421-441$ (1976). Compare Chicago Transit Auth. v. Flohr, 570 F.2d 1305 (7th Cir. 1977) (a 
The judicial treatment of state laws under the labor preemption doctrine provides additional support for concluding that the RLA covers state employees of commuter-freight lines.214 The Supreme Court first fully articulated the doctrine that federal labor statutes generally preempt contrary state laws affecting employee rights in San Diego Building Trades Council v. Garmon. ${ }^{215}$ Writing for the majority, Justice Frankfurter expressed the fear that without preemption, state regulation could effectively dismantle "the comprehensive regulation of industrial relations" formulated by Congress. ${ }^{216}$ The potential conflicts between two law-enforcing authorities and the problem of effectively administering the federal scheme ${ }^{217}$ prompted Justice Frankfurter to conclude:

When the exercise of state power over a particular area of activity threatened interference with the clearly indicated policy of industrial relations, it has been judicially necessary to preclude the States from acting. ...

When it is clear or may fairly be assumed that the activities which a State purports to regulate are protected by $\S 7$ of the $\mathrm{Na}$ tional Labor Relations Act, . . . due regard for the federal enactment requires that state jurisdiction must yield. To leave the States free to regulate conduct so plainly within the central aim of federal regula-

transit system is not a "railroad" subject to Railway Safety Act) with United States v. Massachusetts Bay Transp. Auth., 360 F. Supp. 698 (D. Mass. 1973) (a transit system is a railroad subject to the Act).

In Amalgamated Transit Union Div. 819 v. Byrne, 568 F.2d 1025 (3d Cir. 1977), the court addressed the related issue of whether federal labor policy preempted a conflicting state subsidization program. New Jersey had conditioned its operating subsidies to private transit companies on their adherence to certaim restrictions regarding employee wages. Finding that Congress did not intend to preclude this type of state action, the court upheld the program. Id at 1029-30. New Jersey's program, the court opined, constituted proprietary action, not a governmental attempt to influence the substantive outcome of the bargaining process. Id. But see Lodge 76, Int'1 Ass'n of Machinists v. Wisconsin Emp. Rel. Comm'n, 427 U.S. 132, 153 (1976) (state may not enjoin union's refusal to work overtime: "state attempts to influence the substantive terms of collectivebargaining agreements are . . . inconsistent with the federal regulatory scheme . . .). One coinmentator has strongly criticized the Byrne decision, noting the impact of the state's imterference with working conditions and its psychological effect on the workers. Comment, Labor Preemption and State Subsidized Industries, 78 CoLuM. L. REv. 1332, 1337-39 (1978). The court failed to recognize its decision's implications on federal labor policy. The magnitude of state spending in the private sector creates an enormous potential for altering or even dictating private sector labor contract provisions-"a result clearly at odds with federal labor policy." Id. 1338-39. Admittedly, the state had an interest im providing transportation services to its constituents at the lowest possible cost. Nevertheless, the commentator argues, New Jersey conld have chosen to provide these services itself and to utilize the NLRA exemption of state employers. See id. 1343.

214. See generally Cox, Labor Law Preemption Revisited, 85 HARv. L. REv. 1337 (1972); Note, The Preemption Doctrine: Shifting Perspectives on Federalism and the Burger Court, 75 CoLUM. L. REv. 623 (1975); Note, A Framework for Preemption Analysis, 88 YALE L.J. 363 (1978).

215. 359 U.S. 236 (1959).

216. Id at 239.

217. Id at $242-43$. 
tion involves too great a danger of conflict between power asserted by Congress and requirements imposed by state law. . . . Regardless of the mode adopted, to allow the States to control conduct which is the subject of national regulation would create potential frustration of national purposes. ${ }^{218}$

The Garmon Court did not prohibit states from regulating conduct "so deeply rooted in local feeling and responsibility that, im the absence of compelling congressional direction, we could not infer that Congress had deprived the States of the power to act."219 Consequently, the Court did not overrule the line of cases preserving state jurisdiction to mamtain domestic peace during labor disputes. ${ }^{220}$

The proposed framework explains the results of some labor preemption cases. 221 When states regulate nontraditional imterests, the federal statutory scheme generally preeinpts state regulation. To avoid preemption, however, a state must show that its mterest is demonstrably greater than the federal interest. In New York Telephone Co. v. New York State Department of Labor ${ }^{222}$ the Court upheld a state statute that provided unemployment compensation to strikers, even though the statute undoubtedly affected the collective bargaining process. The Court found no evidence in the NLRA of congressional intent to deny a state the power to enact an unemployment compensation systein. ${ }^{223}$ The proposed analysis would classify this state activity as essential and would find it protected in view of the demonstrably greater state interest in a comprehensive uneinployinent compensation scheine than the federal interest in precluding the scheine. ${ }^{224}$

Under the proposed analysis, a colnunuter-freight rail service is an essential state function. Consequently, to avoid apphication of the RLA, the state must prove that its interest in providing these services is demonstrably greater than the federal interest embodied in the RLA.

218. Id. at $243-44$.

219. Id. at 244.

220. Id. at 247. See also International Union, UAW v. Russell, 356 U.S. 634 (1958) (state court jurisdiction over common law tort action against union for mass picketing and threats of violence upheld); Youngdahl v. Rainfair, Inc., 355 U.S. 131 (1957) (state court may enjoin conduct of striking einployees that is hikely to proınote violence); International Union, UAW v. Wisconsin Employees Relation Bd., 351 U.S. 266 (1956) (state labor relations board ınay enjoin violent union conduct); Umited Constr. Workers v. Laburnum Constr. Corp., 347 U.S. 656 (1954) (state court jurisdiction over coininon law tort action against umion upheld).

221. See Note, A Framework, supra note 214, at 372-89.

222. 440 U.S. 519 (1979). See generally Comment, New York Telephone v. New York State Department of Labor: Limiting the Doctrine of Implied Labor Law Pre-emption, 46 BROOKLYN L. REv. 297 (1980); Comment, Balancing in Labor Law Preemption Cases: New York Telephone Co. v. New York State Departınent of Labor, 32 STAN. L. REV. 827 (1980).

223. 440 U.S. at $540-46$.

224. See notes 136-39 supra and accoinpanying text. 
The federal interest in the RLA is particularly strong. In Brotherhood of Railroad Trainmen v. Jacksonville Terminal Co.,225 the Supreme Court, for example, refused to allow a state to regulate the economic coinbat between parties subject to the RLA. Finding that employees have the right to strike under the RLA, ${ }^{226}$ the Court held that the state had failed to ineet its burden of proving that the regulation of peaceful picketing did not imterfere with the RLA.227

In assessing the state's interest in providing commuter-freight services, a court should examine the nature of the service rather than the label assigned to it by the state government. Thus, the MTA's attempt in United Transportation Union to avert a threatened strike by converting the LIRR into a "public benefit corporation" bears only on whether the LIRR is facially subject to the Taylor law.228 Under the proposed analysis this action does not reinove the line from the constraints of the RLA and the Supreme Court should find that the state interest in providing this non-traditional service does not demonstrably outweigh the federal imterest in the RLA.

Admittedly, under the proposed analysis, the RLA covers employees of rail systems in which the state maimtains or provides freight services but would exempt employees if the state were to discontinue freight operations. This conclusion, however, results from the RLA's specific exclusion of commuter lines.229 For purposes of the RLA, a commuter-freight system is a "carrier" within the Act and subject to its provisions.

\section{CONCLUSION}

Because of the rising costs of providing commuter rail services, state and local governments mcreasingly have acquired privately owned companies to provide this service. When these services are linked to an interstate freight systein, the Railway Labor Act provides the companies' employees with collective bargaining rights. Most courts addressing the question of whether einployees retain these rights after state acquisition have focused on the "essential" nature of the service. This approach misses the more important question of whether

225. 394 U.S. 369 (1969).

226. Id. at $378-79$.

227. Id at 390-93; see id. at 381 ("the potential for conflict . . . and for the imposition of inconsistent state obligations . . . are simply too great to allow each State which liappens to gain personal jurisdiction over a party to a railroad labor dispute to decide for itself what economic self-help that party may or may not pursue").

228. See notes 61-72 supra and accompanying text.

229. 45 U.S.C. \& 151 (1976). 
the federal statute can constitutionally cover the particular state activity.

In answering this last question, the framework proposed in this comment provides a workable solution for determining whether the particular state activity is immune from federal regulation. The tax power and antitrust cases suggest that the tension between two different law-enforcing bodies may best be resolved by distimguishing initially between traditional and essential governmental functions. In regulating traditional governmental functions the federal government must prove that the federal interest embodied in the statute is demonstrably greater than the state interest. In cases involving essential governmental functions the state bears the burden of proving that its imterest is demonstrably greater than the federal imterest. These classifications and the shifting burden of proof provide a workable guide for state and municipal governments in responding to the changing demands of their constituents, while preserving Congress's ability under the commerce power to regulate activities requiring national attention and remedies.

Morris A. Ellison 